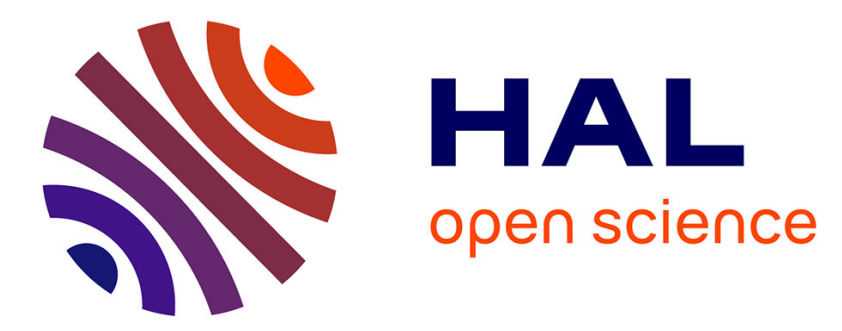

\title{
Bank Ownership and Credit Cycle: the lower sensitivity of public bank lending to the business cycle
}

Thibaut Duprey

\section{To cite this version:}

Thibaut Duprey. Bank Ownership and Credit Cycle: the lower sensitivity of public bank lending to the business cycle. 2013. halshs-00829474

\section{HAL Id: halshs-00829474 \\ https://shs.hal.science/halshs-00829474}

Preprint submitted on 3 Jun 2013

HAL is a multi-disciplinary open access archive for the deposit and dissemination of scientific research documents, whether they are published or not. The documents may come from teaching and research institutions in France or abroad, or from public or private research centers.
L'archive ouverte pluridisciplinaire HAL, est destinée au dépôt et à la diffusion de documents scientifiques de niveau recherche, publiés ou non, émanant des établissements d'enseignement et de recherche français ou étrangers, des laboratoires publics ou privés. 


\section{PARISSCHOOL OF ECONOMICS}

WORKING PAPER N²013-15

Bank Ownership and Credit Cycle: the lower sensitivity of public bank lending to the business cycle

Thibaut Duprey

JEL Codes : G21, G28, G32, H44

Keywords: Lending cycle ; Procyclicality ; Public banking ; Privatisations ; Nationalisations ; Forbearance

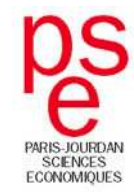




\title{
Bank Ownership and Credit Cycle :
}

\section{the lower sensitivity of public bank lending to the business cycle *}

\author{
DuPREY Thibaut ${ }^{\dagger}$
}

Revised : May 2013

${ }^{*}$ I am grateful to Jean Imbs, Xavier Ragot and Romain Rancière for guidance, as well as Vincent Bouvatier, Régis Breton, Balazs Egert, Benjamin Klaus, Mathias Le, Thomas Piketty and seminar participants at the Bank of France, the Paris School of Economics, the CSAEM (London), the days "Risks in Finance" (Orléans University), the ADRES-AFSE (Strasbourg University) and the Conference on International Macroeconomics and Financial Econometrics (Nanterre University) for helpful comments on previous drafts. This paper builds on my master dissertation defended in June 2011. I gratefully acknowledge financial support from the Bank of France. The opinion expressed herein may not reflect the position of the Bank of France. Any remaining errors are mine.

${ }^{\dagger}$ Paris School of Economics and Bank of France. Campus Paris-Jourdan, 48 boulevard Jourdan, 75014 Paris. E-mail : thibaut.duprey@gmail.com. Tel : +33(0)142924091. 


\title{
Résumé
}

Le présent article analyse le comportement des banques publiques au long du cycle économique. Grâce à une base de donnée unique, de 1990 à 2010, incluant au plus 459 banques publiques dans 93 pays, il est possible de prendre en considération les changements de propriété avec les privatisations et nationalisations en temps de crise, lesquelles tendraient à diminuer les différences entre banques publiques et privées. Je trouve que (i) les prêts des banques publiques sont significativement moins cycliques que ceux des banques privées, (ii) les banques publiques diminuent moins leurs prêts en cas de retournement économique, avec une relation positive entre développement économique et capacité d'absorption des chocs macroéconomiques par les banques publiques, et (iii) les banques privatisées passent d'un régime de faible cyclicité des prêts à une cyclicité proche de celle des banques privées. Ce co-mouvement plus faible des prêts des banques publiques avec les fluctuations économiques révèle à la fois (a) une moindre vulnérabilité du bilan et un financement plus stable des banques publiques, ce qui est cohérent avec un modèle bancaire favorisant les relations avec le client, (b) mais aussi un provisionnement pour pertes décalé dans le temps, symptôme de mauvaise gestion des actifs; la combinaison des deux explications est liée au niveau de développement économique : si les pays développées peuvent être caractérisés par une cyclicité efficiente des prêts des banques publiques, pour les pays moins développés cela risque de retranscrire davantage une allocation inefficace du crédit.

Mots-clefs : cycle du crédit, procyclicité, banques publiques, privatisations, nationalisations, dépréciations différées.

Code JEL : G21, G28, G32, H44.

\begin{abstract}
This paper examines empirically to which extent public banks feature a different pattern in their lending behaviour over macroeconomic fluctuations. Based on a unique dataset from 1990 to 2010, including at most 459 public banks in 93 countries, I can handle ownership change by including records on privatisations as well as nationalisations during banking crisis, which would otherwise blur the picture. I find that (i) public bank lending is significantly less cyclical than that of private banks, (ii) public banks cut less on their loans during economic downturns, with a positive relation between economic development and their ability to absorb macro shocks, and (iii) privatised banks switch from a regime of low to high lending cyclicality. Then, the lower co-movement of public bank loans with macroeconomic fluctuations reveals both (a) a less vulnerable balance sheet structure and more stable financing sources, which is consistent with a lending relationship business model, (b) as well as delayed loan deterioration, which is a symptom of forbearance and inefficient loan management; the actual combination of the two is not orthogonal to economic development, with high income countries more likely to feature efficient public bank lending cyclicality, while evidences suggest it may reveal an inefficient credit allocation for less developed countries.
\end{abstract}

Keywords : lending cycle, procyclicality, public banking, privatisations, nationalisations, forbearance.

JEL Classification : G21, G28, G32, H44. 